\title{
FACTORS DETERMINING SATISFACTION WITH THE STUDIES OF THE STUDENTS OF SCHOOLS OF HIGHER EDUCATION
}

\author{
Valdonè Indrašienė \\ Mykolas Romeris University, Institute of Education and Social Science, Lithuania \\ Odeta Merfeldaitè \\ Mykolas Romeris University, Institute of Education and Social Science, Lithuania \\ Asta Railienė \\ Mykolas Romeris University, Institute of Education and Social Science, Lithuania \\ Violeta Jegelevičienè \\ Mykolas Romeris University, Institute of Education and Social Science, Lithuania \\ Irena Žemaitaitytè \\ Mykolas Romeris University, Institute of Education and Social Science, Lithuania
}

\begin{abstract}
In the modern world conditioned by scientific-technical progress and globalisation it is becoming tricky for schools of higher education to respond to continuously changing needs of the labour market, to secure the expectations of the students towards the selected sought education and its realisation in certain situations of activities. Satisfaction of students with the studies and employment of graduates becomes one of the key criteria of the quality of studies which influences the academic activity of universities. The study introduces the factors which determine the satisfaction of the final years students with their studies. Quantitative research was selected - a representative survey was performed. The study population consisted of the students of the Lithuanian higher schools (universities and colleges) ( $n=459)$. It has been established that the key factors in the selection of study programs (demand of the study program on the labour market, the self-set career goals, clear potentials for professional career and links between the personal needs and the program) demonstrates the ability of students to plan and make decisions regarding their careers. When selecting a study program, the factors orientated towards assessment of personal achievements and own attitudes towards the profession (the selected graduation exams and their results, the prestige of the profession and the leisure time likings) are not less important. The key factors of satisfaction with the selected study program relate to the fact that the study program contributes to personal development, to better employment and career prospective. Students are satisfied with the selected study program because of favourable educational study environment, of a possibility to gain practical skills and of the applicable system of assessment.
\end{abstract}

Keywords: career, satisfaction with studies; students of schools of higher education; study programs. 


\section{Introduction}

One of the key goals of the Lithuanian education is to help an individual and the society to respond to the basic challenges of today and to make use of the opening possibilities as much as it is possible. Higher education is being based on the ambition to implement the results of research into the process of studies in the most efficient way and, through it, into the life of the society, striving for high quality of social welfare and of the life of the individuals. Therefore, it is becoming tricky for schools of higher education to respond to continuously changing needs of the labour market, to secure the expectations of the students towards the selected sought education and its realisation in certain situations of activities. Students' satisfaction with their studies and employment of graduates become the most important criteria with the influence on the academic activity of universities (Pukelis, 2009; Pukelyte, 2010). In the opinion of scientists (Wach, Karbach, Ruffing, Brünken, \& Spinath, 2016), one of the relevant issues the universities continuously have to deal with is teaching young people to be successful students and become successful employees. In this context the issue of the quality of science and studies becomes particularly relevant, and defined by the level of management of a school of higher education, the up-to-date study programs, the professionalism of the teachers providing the latest knowledge of science, international exchange of teachers and students, transparent systems for motivation of the academic society and etc. (Reavil, 1998; Valuckienè, 2012).

The quality of studies depends on many factors: the motivation of the students, the system of study organization, the material/technical facilities, the overall social-cultural environment of a school of higher education, the quality of both individual and joint activities of each and every employee of an institution of higher education (Duffy, Allan, \& Bott, 2012). The researches (Haman, Donald, \& Birt, 2010; Dukhan, Cameron, \& Brenner, 2011) disclose that in the process of improvement of quality of studies the issue of analysis of students' expectation and satisfaction with studies becomes of utmost importance. When students have high expectations and their satisfaction with their studies is low, reaction from the school of higher education is a must, expressed as performance of various interventions: providing assistance to the students, improving subjects and/or study programs and etc. According to scientists (Bulotaité, Pociūte, Bliumas, \& Dovydaitiené, 2012), in satisfaction of students with their studies mostly relates to their motivation to study. Satisfaction of students with their studies is not just their response to the situation of learning and experience, but it is also the response to the aspects of personal growth and social development. Satisfaction with studies is also a part of the satisfaction with the life of a young individual (Wiers-Jenssen, Stensaker, \& Grogaard, 2002; Diamantis \& Benos, 2007; Wach et al., 2016). The research performed by Kell \& Motowidlo (2012) 
showed that experience of learning and satisfaction with studies encourage students to be more obliged to the profession or to revise the goals and choices of their career.

In Lithuania students' satisfaction with studies is not a problem being widely analysed. Some researches show that satisfaction with studies is high and does not depend on the study program (Bulotaite et al., 2012). Results of other studies (Žekevičienè, 2009) identify specific factors, such as cultural, sex, differences of attitudes of service providers and consumers, selection of a study term for interviewing students and etc., which have influence on students' expectations, satisfaction with studies and understanding of the quality of studies.

The purpose of the research is to identify the factors which determine satisfaction of the students with their studies.

The methods of the research: analysis of scientific literature and quantitative research.

\section{Research methodology}

Aiming to investigate satisfaction with the studies of the students of the final years the quantitative research was chosen: a representative questionnaire survey was performed. The study population consisted of the students of the final years of the Lithuanian schools of higher education (universities and colleges). By the quantitative research it was aimed to substantiate statistically the essential features of the research theme, to reduce the number of the primary features and to disclose the regularity and significance of their functioning (Bitinas, 2006).

A representative questionnaire survey was performed (reliability 95 per cent, error 5 per cent); 459 students of the Lithuanian schools of higher education in the final years were surveyed. In order to have the scope representing all general population and be representative, the multi-stage probability sampling method was applied where several sampling methods were combined: clustered, stratified and simple random sampling.

The instrument of the quantitative-empiric research was a questionnaire. Questionnaires are convenient because, based only on the data collected from only a part of the population (sample), it is possible to make reliable and validated conclusions regarding the entire population: all students of the final years of schools of higher education (Gaižauskaitė \& Mikènè, 2014).

The questionnaire consists of 6 blocks of questions: selection of the study program; factors determining satisfaction with the studies; environment of the studies; administration / management of the studies; assistance for a student; demographical data.

During the pilot research the internal consistency of the prepared instrument of the research was checked and the Cronbach $\alpha$ coefficient was calculated. The 
obtained results of the calculation allows stating that internal consistency of all scales of the questionnaire is high, or very high, i.e. Cronbach $\alpha$ coefficient varies from 0.708 to 0.921 (Vaitkevičius \& Saudargienè, 2006).

The questionnaire survey took place in September - October 2018, performed by serving the students of the final years from schools of higher education with printed questionnaires. All members participated in the research voluntarily. Prior to the questionnaire survey the respondents were briefly presented the goal of the survey, the possibilities to use the data of the research and the time-limit for the return of the questionnaire. The participants agreed to participate in the research on their free will; therefore, they had the right to discontinue their participation in the survey any time. In order to secure anonymity of the respondents and confidentiality of the presented answers, the principle of secrecy was observed; the participants filled in the questionnaire anonymously.

The collected data were processed using the software IBM SPSS Statistics 22. The data analysis was performed using the means of descriptive statistics (distribution of the answers (frequency percentage) to each question in the questionnaire were described), the links between variables, parametric and non-parametric assumption (depending on the level of the measuring of the variables under analysis) were checked, $\chi^{2}$, Mann-Whitney criteria were applied; the Spearman rank correlation coefficient $\left(\mathrm{r}_{\mathrm{s}}\right)$ was calculated. For assessment of the statistical significance the level $\mathrm{p}<0.05$ was applied (Vaitkevičius \& Saudargienè, 2006).

\section{Results of the research}

During the research special attention was paid to find out the factors which had determined the choice of the study program. It has been established (Table 1) that, in the opinion of the majority of the respondents the choice of studies was influenced by the self-set career goals (68.6 per cent), the correlation between the study program and the favourite educational subjects (64.7 per cent), clear professional career prospective (62.7 per cent), the demand for the chosen study program on the labour market (58.3 per cent) and the links between the study program and personal needs (53.8 per cent).

Less than a half of the respondents indicated that the choice of the study program was determined by the selected graduation examinations and their results (45.9 per cent), the prestige of the profession ( 45.1 per cent) and leisure time likings (41.8 per cent). A bit more than one-third of the respondents indicated that their choice of studies was determined by the possibilities for self-expression (intellectual, artistic) (39.6 per cent). 
SOCIETY. INTEGRATION. EDUCATION

Proceedings of the International Scientific Conference. Volume I, May $22^{\text {th }}-23^{\text {th }}, 2020.222-232$

Table 1 Key factors determining the choice of the studies (per cent)

\begin{tabular}{|c|l|c|c|c|c|c|c|}
\hline $\begin{array}{c}\text { Item } \\
\text { No }\end{array}$ & \multicolumn{1}{|c|}{ Statements } & $\begin{array}{c}\text { Surely } \\
\text { yes }\end{array}$ & Yes & $\begin{array}{c}\text { Neither } \\
\text { yes, } \\
\text { nor no }\end{array}$ & No & $\begin{array}{c}\text { Surely } \\
\text { no }\end{array}$ & $\begin{array}{c}\text { No } \\
\text { answer }\end{array}$ \\
\hline 1 & $\begin{array}{l}\text { Selected graduation } \\
\text { examinations and their results }\end{array}$ & 16.3 & 29.6 & 19.8 & 20.5 & 12.6 & 1.1 \\
\hline 2 & $\begin{array}{l}\text { The study program relates to } \\
\text { favourite education subjects }\end{array}$ & 20.0 & 44.7 & 17.4 & 11.5 & 5.7 & 0.7 \\
\hline 3 & Career goals & 27.0 & 41.6 & 20.5 & 7.0 & 2.4 & 1.5 \\
\hline 4 & $\begin{array}{l}\text { Demand for the chosen study } \\
\text { program on the labour market }\end{array}$ & 20.0 & 38.3 & 25.1 & 11.1 & 4.4 & 1.1 \\
\hline 5 & Professional prestige & 13.5 & 31.6 & 26.6 & 18.5 & 8.3 & 1.5 \\
\hline 6 & Good financial situation in future & 11.5 & 29.0 & 32.5 & 16.3 & 9.6 & 1.1 \\
\hline 7 & $\begin{array}{l}\text { Clear professional career } \\
\text { possibilities }\end{array}$ & 21.1 & 41.6 & 22.2 & 7.4 & 5.0 & 2.6 \\
\hline 8 & $\begin{array}{l}\text { Possibilities for self-expression } \\
\text { (intellectual, artistic) }\end{array}$ & 11.1 & 28.5 & 29.0 & 17.6 & 12.6 & 1.1 \\
\hline 9 & Leisure time likings & 9.8 & 32.0 & 24.6 & 20.7 & 11.3 & 1.5 \\
\hline 10 & $\begin{array}{l}\text { Study program relates to } \\
\text { personal needs }\end{array}$ & 15.7 & 38.1 & 24.4 & 13.7 & 6.5 & 1.5 \\
\hline
\end{tabular}

The analysis of the research data disclosed that more than a half of the respondents (those answering to the statement contributes and contributes very much) noted that the chosen program of the studies contributes to increase of employment possibilities (53.4 per cent); to increase of career prospects (51.4 per cent) and to their personal development (68.2 per cent). It should be noted that approximately one-third of the respondents (33.8 per cent) indicated that the chosen program of studies more contributes rather than not contributes to the increase of their entrepreneurship skills.

It has been established (Fig. 1) that, should they had an opportunity to reconsider their choice of studies, over a half participants of the research (58.2 per cent) would chose the same study program at the same school of higher education. The students of the final years having studies as their first priority are more apt to approve this statement $(\chi 2=43.057 ; \mathrm{p}=0.02)$. 


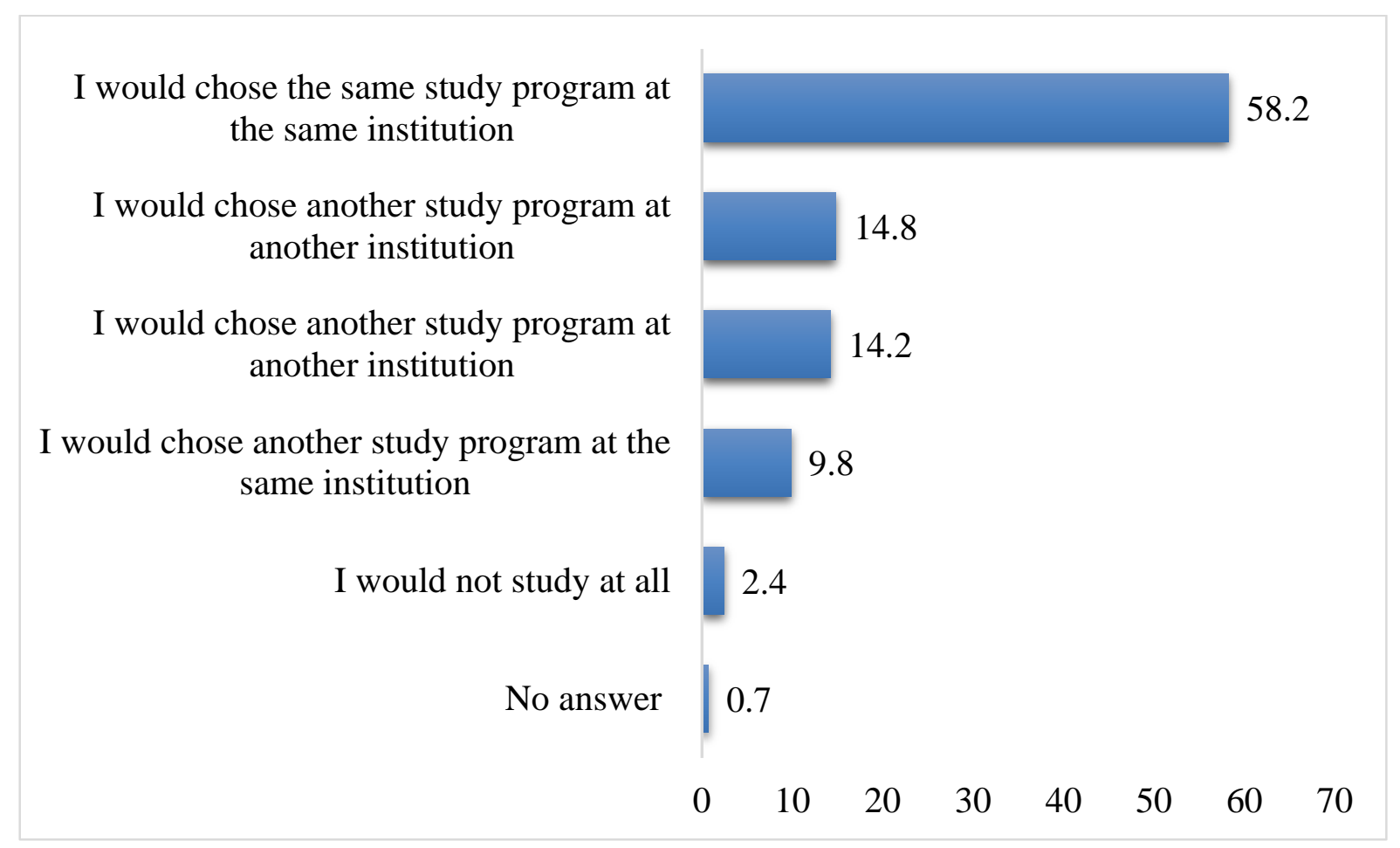

Figure 1 Re-consideration of the study program (per cent)

Analysing the satisfaction with the environment of the studies of the final year students it appeared that almost a half of the students (answering to the statement satisfied and very satisfied) are satisfied with adaptation for studies of classrooms and laboratories (45.3 per cent) and with the technical provision of class-rooms. But more than two-fifths of the interviewed (answering to the statement not satisfied at all and not satisfied) (43.5 per cent) expressed their dissatisfaction with the adjustment of schools of higher education for the persons with physical disabilities.

Assessing the services provided by libraries, the participants of the research are satisfied with the work hours of libraries (66.9 per cent), the accessibility of resources of libraries (e-resources, databases) (55.4 per cent) and the newness of libraries resources (46.6 per cent) (answering to the statement satisfied and very satisfied). Over a half of the students - participants in the research - are satisfied with availability of connection to the library resources from their place of residence (from home or a hostel) (53.6 per cent). Over one-third of the interviewed (answering the statement not satisfied at all and not satisfied) (38.1 per cent) are not satisfied with the trainings and consultancy activities organised by libraries. 
The analysis of empiric data shows that the majority of students are satisfied with the programs of their studies (the mean $\mathrm{M}^{1}$ varies from 3.05 to 3.85). It has been noticed that the students are the most satisfied with the culture of communication tools with the teachers $(\mathrm{M}=3.85)$, the culture of communication tools within the group $(M=3.80)$, the study program $(M=3.65)$, the practical experience transferred by the teachers $(\mathrm{M}=3.61)$ and with the emotional atmosphere during lectures and seminars $(\mathrm{M}=3.55)$. The students are slightly less satisfied with the assessments made by the teachers $(\mathrm{M}=3.48)$, the theoretical knowledge transferred by the teachers $(\mathrm{M}=3.46)$, the program content (3.43), the possibilities for international academic mobility $(\mathrm{M}=3.42)$, the learning (selflearning) methods applied by the teachers $(M=3.42)$. The students are the least satisfied with the time-tables of lectures and seminars $(\mathrm{M}=3.19)$, the proportion of the remote and contact work in the study program $(\mathrm{M}=3.19)$, the possibility to select individual study subjects $(M=3.12)$ and the price of the studies $(M=3.05)$.

Thus, over a half of the students (59 per cent) are highly satisfied (answering to the statement satisfied and highly satisfied) with their study program. Only less than one-fifth (15.9 per cent) of the interviewed (answering to the statement not satisfied at all and not satisfied) are not satisfied with their study program. 24.4 per cent of the interviewed are more satisfied with their study program than not satisfied (assessed their study program 3 points of 5 ).

Slightly more than a half of the interviewed (answering to the statement satisfied and highly satisfied) are satisfied with the culture of communication tools with the teachers (66.8 per cent) and with other students (67.3 per cent), with the emotional atmosphere during lectures and seminars (56.6 per cent), presentation of the lecturers' practical experience (58.2 per cent), the scope of practice within the study program (53.4 per cent) and with the assessment of students (53.3 per cent).

The least satisfied the students are with the price of the studies (33.8 per cent), possibilities to select individual subjects for studies (30.9 per cent), the time-tables of the lectures/seminars (30.5 per cent) (answers to the statement not satisfied at all and not satisfied). Nearly a quarter of the students are not satisfied with a possibility to choose the form of their studies (remote/contact) (24.4 per cent) and the proportion of remote and contact work in their study program. This leads to assumption that the expectations of the students regarding combination of remote and contact work in their study programs are not satisfied.

\footnotetext{
${ }^{1} \mathrm{M}$ - the mean (the scale from 1 to 5), when: 1- not satisfied at all, 2 - not satisfied, 3 - satisfied in part, 4satisfied, 5 - highly satisfied
} 
It has been established that over two-thirds of the final year students (answering to the statement satisfied and highly satisfied) are satisfied with the assistance provided by the teachers: consultancy ( 62.5 per cent), the presented material of lectures and seminars (66.2 per cent), the assistance of teachers in finding a place for practice (52.5 per cent) and in preparation of research works or group projects (52.2 per cent). But the feed-back regarding performed tasks was positively assessed by over one-third of the respondents (37.1 per cent). Similar number of the respondents (34.6 per cent) did not answer the question, which allows making an assumption that the students did not get any feed-back. As "other" the students mentioned "good willingness" of the teachers, their "advice in guiding proper direction".

The students of colleges are more satisfied with consultancies provided by their teachers (the mean rank value of the university students - 216.36, of the college students -241.69 , $\mathrm{p}=0.035$ ), with the presented material of lectures/ seminars (the mean rank value of the university students -214.66 , colleges 244.23, $\mathrm{p}=0.012$ ), with the feed-back regarding performed tasks (the mean rank value of the university students -210.10 , of the college students -249.94 , $\mathrm{p}=0.001$ ). But the students of universities are more satisfied with the assistance in finding a place for practice (the mean rank value of the university students 239.37, of the college students -207.23 , $\mathrm{p}=0.008$ ).

Analysing the forms in which the teachers provide their assistance (Fig. 2) it appeared that the students (answering to the statement satisfied and highly satisfied) are satisfied with the assistance provided by e-mail (65.1 per cent) and with "live" consultations). Slightly less than a half of the students are satisfied with the assistance provided on virtual environment (48 per cent) and in social media (35.3 per cent). Almost a half of the respondents (48.6 per cent) (answering to the statement not satisfied and not satisfied at all) are not satisfied with the assistance provided by the teachers on Skype.

The students of colleges are more frequently $(p<0,01)$ satisfied with assistance provided by their teachers in the virtual learning environment (the mean rank value of the university students -211.29 , of the college students -249.27 , $\mathrm{p}=0.002$ ), in social media (the mean rank value of the university students -202.06 , of the college students $-263.10, \mathrm{p}=0.000$ ), by telephone (the mean rank value of the university students -204.29 , of the college students $-259.75, \mathrm{p}=0.000$ ) and by Skype (the mean rank value of the university students -210.34 , of the college students -249.36 , $p=0.000$ ). 
Proceedings of the International Scientific Conference. Volume I, May $22^{\text {th }}-23^{\text {th }}, 2020.222-232$

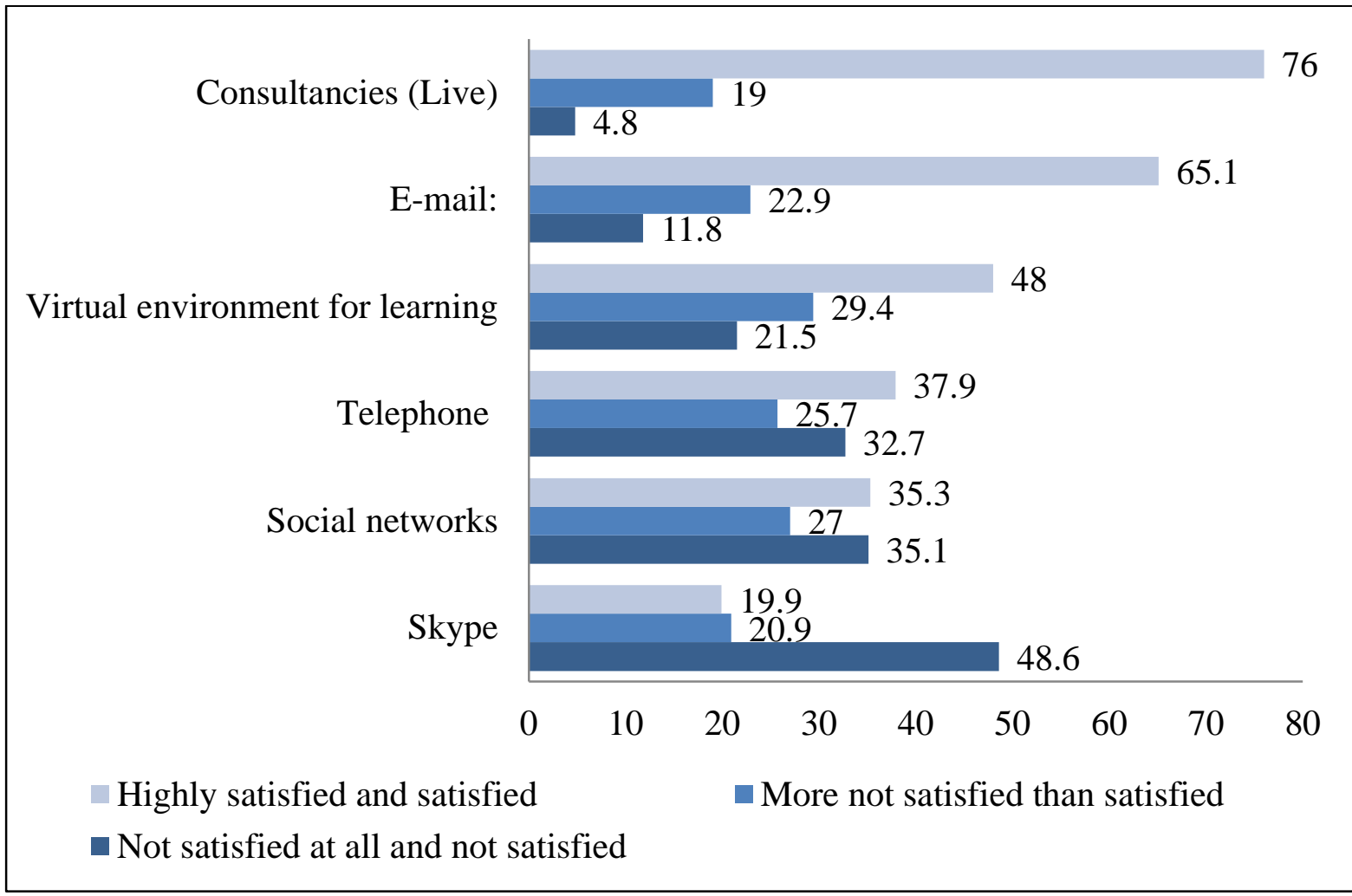

Figure 2 Forms of the teachers' assistance (per cent)

The data of the performed research disclosed that over a half of the students of the final years (53.6 per cent) (answers to the statement satisfied and highly satisfied) are satisfied with the assistance in getting social support in their school of higher education (social grants, reduction of the school fees, possibility to pay school fees in instalments, nominal grants). Additionally, slightly less than a half of the students are satisfied with a possibility to get psychological aid (39.3 per cent) and legal aid (39.6 per cent) free of charge, with a possibility to combine studies and work (45.6 per cent). Slightly over two-fifths of the students of the final years are not satisfied with the services of public catering available in their school of higher education (42.2 per cent).

The students of colleges are more satisfied with a possibility to get psychological consultancy (the mean rank value of the university students 215.80, of the college students $-242.52, \mathrm{p}=0.029$ ) and legal aid free of charge (the mean rank value of the university students - 217.96, of the college students 239.28, $\mathrm{p}=0.013)$. The students of colleges more frequently approve the statement that they have a possibility to combine the studies and work (the mean rank value of the university students -214.35 , of the college students -244.69 , $p=0.000$ ).

The data of the research show that the students of the final years (answering to the statement satisfied and highly satisfied) are satisfied with the assistance regarding practice (60.3 per cent) and career possibilities (55.7 per cent). Less than a half of the students of the final years are satisfied with the assistance 
provided by their school of higher education on the use of scientific information (43.4 per cent) and on organisation of the process of studies (44.3 per cent). Approximately a half of the students are satisfied with possibilities for international exchange (46.4 per cent) and for self-expression (44.4 per cent). The students are the most unsatisfied (answering to the statement not satisfied and not satisfied at all) with the assistance of their school of higher education regarding electronic/remote studies (25.7 per cent) and regarding self-expression (21.6 per cent).

\section{Conclusions}

The key factors in the selection of study programs (demand for the study program on the labour market, self-set career goals, clear potentials for professional career and links between the personal needs and the program) demonstrate the ability of the students to plan and to make decisions regarding their careers. The factors of not less importance in the selection of the study program -: the selected graduation exams and their results, the prestige of the profession and leisure time likings - are orientated towards assessment of achievements and own attitudes in respect of the profession. The students do not incline to re-consider the selection of their studies; they would choose the same program for their studies.

The key factors of satisfaction with the study program are as follows: the professionalism of teachers, the culture of communication tools, the environment favourable for studies and the organisation of the process of studies. Students are satisfied with the selected study program because of favourable educational study environment, of a possibility to gain practical skills and of the applied system of the achievements assessment. The students are not satisfied with the price of their studies, with possibilities to choose certain subjects for studies, with the timetables of lectures/seminars and with the organisation of remote studies.

The adjustment of class-rooms and laboratories for studies and the technical supply satisfy the students, but they are not satisfied with adjustment of schools of higher education for the persons with physical disabilities. The students are satisfied with the work hours of libraries, accessibility of library resources and newness of library resources. But they are not satisfied with training and consulting activities organised by the library.

Schools of higher education provide variety of assistance for the students: students get advice, training material, are assisted in finding a place for practice and in preparation of research or project work. Students are satisfied with a possibility of getting social assistance, psychological and legal aid free of charge, with a possibility to combine studies and work. 
SOCIETY. INTEGRATION. EDUCATION

Proceedings of the International Scientific Conference. Volume I, May $22^{\text {th }}-23^{\text {th }}, 2020.222-232$

\section{References}

Bitinas, B. (2006). Edukologinis tyrimas: sistema ir procesas. Vilnius: Kronta.

Bulotaitè, L., Pociūtè, B., Bliumas, R., \& Dovydaitienè, M. (2012). Socialinių mokslų studentų psichologinès gerovès, patiriamo streso ir subjektyvaus sveikatos vertinimo sąsajos. Visuomenés sveikata, 3(58), 85 -92.

Diamantis, G.V., \& Benos, V.K. (2007). Measuring student satisfaction with their studies in an International and European Studies department. Operational Research. An International Journal, 7(1), 47-59.

Duffy, R.D, Allan, B.A., \& Bott, E.M. (2012). Calling and Life Satisfaction Among Undergraduate Students: Investigating Mediators and Moderators. Journal of Happiness Studies, 13(3), 469-47. DOI 10.1007/s10902-011-9274-6

Dukhan, Sh., Cameron, A., \& Brenner, E.A (2012). The Influence of Differences in Social and Cultural Capital on Students' Expectations of Achievement, on their Performance, and on their Learning Practices in the First Year at University. The International Journal of Learning, 18(7), 337-351. DOI: 10.18848/1447-9494/CGP/v18i07/47692

Gaižauskaitè, I., \& Mikènè, S. (2014). Socialiniu tyrimu metodai: apklausa. Vilnius: Mykolo Romerio universitetas.

Haman, J., Donald, J., \& Birt, J. (2010). Expectations and Perceptions of Overseas Students in a Post-graduate Corporate Accounting Subject: A Research Note. Accounting Education, 19(6), 619 - 631. DOI:10.1080/09639284.2010.502329

Kell, J.H., \& Motowidlo, S.J. (2012). Deconstructing Organizational Commitment: Associations Among Its Affective and Cognitive Components, Personality Antecedents, and Behavioral Outcomes. Journal of Applied Social Psichology, 42(1), 213-251. DOI:10.1111/j.1559-1816.2011.00874.X

Pukelis, K. (2009). Gebèjimas, kompetencija, mokymosi/studijų rezultatas, kvalifikacija ir kompetentingumas: teorinè dimensija. Aukštojo mokslo kokybè/The Quality of Higher Education, 6(12), 12-35.

Pukelyte, R. (2010). Universitetinių studijų kaip paslaugos kokybės vertinimas: dimensijos ir kriterijai. Aukštojo mokslo kokybè / The Quality of Higher Education, 7(14), 155-175.

Reavill, L.R.P. (1998). Quality assessment, total quality management and the stakeholders in the UK higher education system". Managing Service Quality: An International Journal, 8(1), 55-63. DOI: https://doi.org/10.1108/09604529810199395

Vaitkevičius, R., \& Saudargienè, A. (2006). Statistika su SPSS psichologiniuose tyrimuose. Kaunas: VDU leidykla.

Valuckienè, J. (2012). Studijų, grindžiamų skirtingomis edukacinėmis paradigmomis, kokybės vertinimo parametrai. Studijos šiuolaikineje visuomenejel Studies in Modern Society, 3(1), 275-286.

Wach, F.S., Karbach, J., Ruffing, St., Brünken, R., \& Spinath, F.M. (2016). University Students' Satisfaction with their Academic Studies: Personality and Motivation Matter. Frontiers in Psychology, 16. DOI: https://doi.org/10.3389/fpsyg.2016.00055

Wiers-Jenssen, J., Stensaker, B., \& Grogaard, J.B. (2002). Student Satisfaction: towards an empirical deconstruction of the concept. Quality in Higher Education, 8(2), 183-195. DOI:https://doi.org/10.1080/1353832022000004377

Žekevičienè, A. (2009). Aukštojo mokslo institucijų paslaugų kokybės tyrimai servqual metodu. Ekonomika ir vadyba/Economics \& Management, 14, 1107-1113. 